\title{
ORGANIZATIONAL AND ECONOMIC MECHANISM ON THE SUSTAINABLE USE STIMULATION OF AGRICULTURAL APPOINTMENT LAND
}

\author{
O.P. Atamaniuk, PhD Candidate in Economics, \\ Researcher at the Laboratory of balanced nature management, Institute of \\ Agroecology and Nature Management of NAAS \\ H.I. Hreshchuk, PhD Candidate in Economics, \\ Associate Professor of the Department of Geodesy and Geoinformatics, Lviv \\ National Agrarian University \\ E-mail: atamanuk.lena@gmail.com
}

It is well-known that the use of incentives should lead to an improvement of the existing economic, environmental and social status, to raising the level of economic indicators for the benefit of the person who provides incentives and who is the object of stimulation. The current socio-economic conditions dictate the need to find effective forms of land management and rational land use management, correcting mistakes and resolving existing issues. This is possible only after all agricultural land use is fully provided with the necessary land management works. These issues can be solved by implementing the planning documents for the development of territories (national, regional, local, etc.). They put in place an algorithm of action to address the issue, but the greatest advantage of the proposed development program is the possibility of developing a land management process on agricultural lands. Clear financing of development programs, allows to ensure the implementation of the outlined plans for the implementation of land management works that are necessary on agricultural land. But in the context of the limited economic opportunities of Ukraine, the financing of land management measures provided for by the program should be only partially depending on the possibilities and level of environmental issues of land use.

Keywords. Agricultural appointment land, sustainable use, stimulation, land management mechanism, development program, land management.

\section{Formulation of the problem.}

Agricultural appointment lands in Ukraine and in the world become more and more valuable every year. Undoubtedly, the reason for this is an increase in the food needs of mankind. At the same time, the use of rural lands in Ukraine occurs in violation of the ma- jority of scientifically grounded norms and neglect of legislative acts. A wide range of proposals and recommendations are presented to ensure sustainable use of agricultural land by modern science, most of them focus on the use of components that are offered by modern land management. In spite of this, there is still no effective incentive for 
landowners and land users to scientifically grounded land use by methods that include land-use mechanisms.

\section{The purpose of this article.}

The aim of the study is to improve the existing mechanism for the promotion of sustainable use of agricultural land. In accordance with the stated goal, the article supposes to solve the following tasks: to identify the main components of modern incentives for sustainable use of land, to identify the main causes of low level land management of land resources, to propose an algorithm that can stimulate rational land use with the use of land management tools.

\section{Analysis of recent research and publications.}

Works by D.I. Babmindra, V.M. Budziak, O.S. Budziak, H.D. Hutsuliak, D.S.Dobriak, A.H.Martyn, A.Ia. Sokhnych, M.H. Stupen, N.Ie. Stoiko, A.M. Tretiak, V.M. Tretiak etc devoted to the study of sustainable use of agricultural lands. Issues of stimulating the development of the land management process as a pledge of sustainable use of agricultural land use were solved by such scholars as A.V. Barvinskyi, D.S. Dobriak, O.S. Dorosh, Y.M. Dorosh, T.O. Yevsiukov, A.H. Martyn, M.P. Stetsiuk, A.M.Tretiak, R.V. Tykhenko, A.M. Shvorak etc. However, current realities require the continuation of the search for additional elements for the mechanism of stimulation of sustainable use of agricultural land, which will enable the development of land management process, which in modern economic and organizational conditions, needs state support and scientific improvement.

\section{Materials and methods of research.}

In the process of research, the following methods were used: monographic (analysis of scientific works on the issue under study), system-structural and comparative analyzes (study of theoretical aspects concerning the application and use of tools for the promotion of the organization and protection of agricultural land); dialectical (the current state of the research issue and proposals for its further development), computational and constructive (research and analysis of the features of stimulation of sustainable use of agricultural land), abstract-logical (theoretical generalizations and formulation of conclusions), etc.

\section{Results of the research and their discussion.}

In the conditions of private ownership of land, state policy in the field of land protection should aim at combining environmental, private and public values on the basis of the approach of encouraging land owners and land users to adopt balanced solutions in the field of land use, which needs to improve the legal regulation of the protection of private lands, the development of voluntary economic methods of land conservation, the regulation of practices, methods and technologies of environmentally sound management [1]. Therefore, in order to ensure that land use is carried out in modern socio-economic realities, the landowner or land user must create conditions in which one will be obliged and able to carry out all necessary land management and other measures for the implementation of rational land use.

In the general sense, the promotion of rational land use is associated with 
material rewards or sanctions. Since the challenge of sustainable use of agricultural land in Ukraine has long existed, there is, accordingly, a fairly wide range of means of stimulating rational land use for today. We have completed an analysis of the existing scientific and legislative support of the issue of stimulation of sustainable land use, as a result, the components that should be included in the mechanism of stimulation of sustainable use of agricultural land are identified (Figure 1). So as pictured on fig. 1, the implementation of sustainable land use requires the work of economic, environmental, administrative and social groups, which are divided into a significant number of components.

From the components of the incentive mechanism for the sustainable use of agricultural land, we focus on the programs and strategies for the development of territories. Under the current conditions, it is the most effective component for stimulating land man- agement of the organization and land protection. Since the implementation of such work requires significant sources of funding, the overcoming of a large number of bureaucratic barriers [2], the most effective development program can be a key element in promoting sustainable use of agricultural land. After all, the search for sources of funding is one of the main deterrent factors in the development of land management process on agricultural lands.

Territorial development programs and strategies, public attention, social consciousness and the reduction of bureaucratic barriers are components that, as a rule, were not entrusted with the task of ensuring the sustainable use of agricultural land, these issues were addressed through a variety of economic instruments. These include: preferential crediting and taxation; exemption from payment of taxes for land plots that are in the state of agricultural development and during the improvement of their

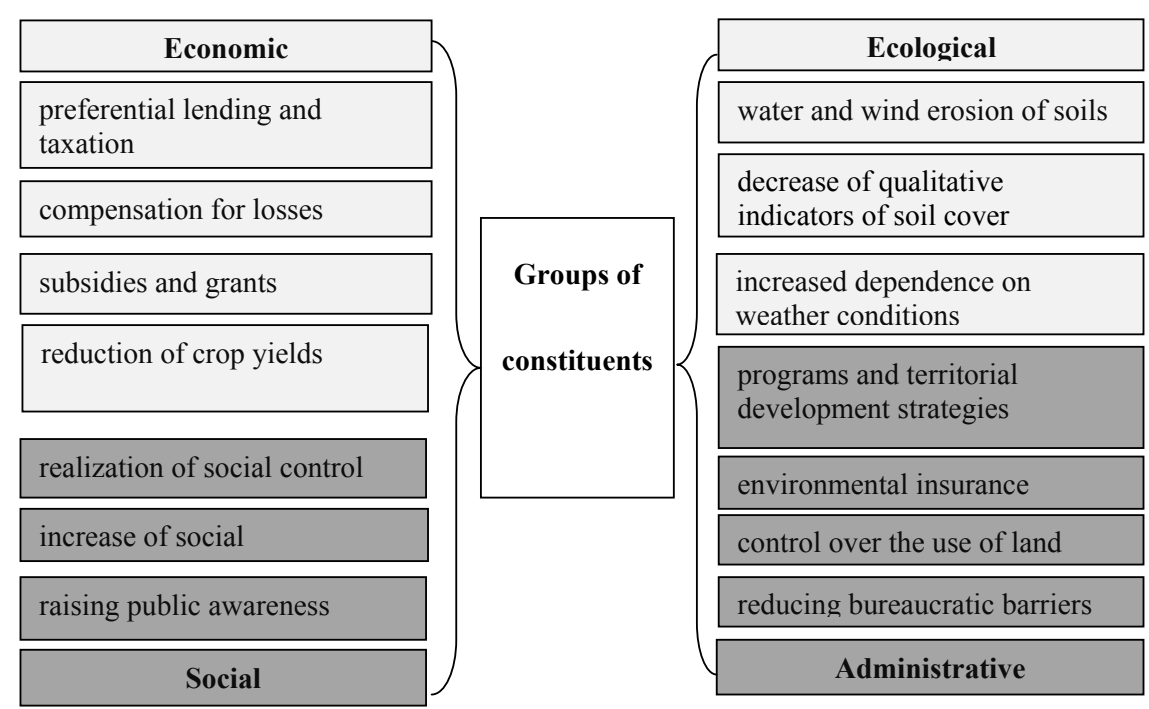

Figure 1 Components of the mechanism on stimulation of agricultural land sustainable use 
condition; compensation of expenses and loss of income through conservation of land; providing state subsidies and subsidies to farms conducting landbased measures; improving the pricing policy for the sale of environmentally friendly products. There are also compulsory levers of influence, which include: payment of land use; additional taxation of the use of environmentally hazardous means and measures; charges for environmental pollution, including deterioration of soil quality, penalties for violation of the principles of environmentally-safe land use; redemption of the right to pollution (environmental license) and environmental insurance. All these levers have certain results, but their impact is too small to talk about sustainable land use [2].

To correct ecological, economic and public mistakes in using land resources and to create conditions for application of land management tools can be by creating a corresponding program for the development of the region. The main priorities that should include such a program should be:

- consideration of agro-climatic, organizational and social peculiarities;

- increase of social role and consciousness;

- rational financial support of the program;

- application of necessary land management tools.

Let's add that the program of organization and protection of agricultural land should be implemented in stages, providing a logical implementation of all the tasks set before it.

Having analyzed the main planning documents of development in Ukraine, one can note insufficient attention to the issue of sustainable use of agricultural land. In programs and strategies, separate measures are taken to preserve soil fertility, improve land reclamation systems, etc. The authority to perform these tasks is entrusted to lower-level administration (district, village, settlement councils). But, according to the author, to the lands of agricultural purpose, their state, organization and protection it is necessary to implement a more detailed approach, which should be implemented in a separate program of development. Its realization should be provided by the landowners and land users themselves, under the control and financing of the respective administrations.

Under the current conditions, it is possible to ensure the sustainable use of land resources by implementing a regional program for the development of land-use machinery on agricultural lands. This would be the most effective financial source for landowners and land users when implementing land management documentation, which ensures the rational use and restoration of quality land resources. Currently, the system of regional programs aimed at ensuring sustainable land use is very poorly developed in Ukraine. The last such program, for example, for the Lviv region, was funded and operates in 2012-2016. But it almost ends up and has not been fully realized.

The logical scheme of the stages of the regional program for the development of land management mechanism on agricultural lands is depicted in Fig. 2. As can be seen from Fig. 2, the program for the development of a land management mechanism on agricultural lands consists of three phases and two tasks that need to be implemented during the entire program period. One aspect of the program is to increase the role of society, the rural population must increase knowledge about sustainable land use 
and become the main driver of its development. Increasing public attention to the sustainable use of agricultural land, may be part of a group of stimulating levers of influence on agrarian formation. Territorial bodies of land resources need to continue to provide explanatory and informative work on the appropriateness of the use of land management tools, but it is necessary to handle it not only with the heads of agribusiness, but also with simple peasants - owners of land shares (units).

Since the vast majority of owners of land shares (shar units es) are elderly people living in rural areas, in order to ensure the maximum population appearance, such meetings should take place only on the territories of the respective village (town councils) by the previous announcement and personal invitation. Society should clearly understand how and for what purpose it is necessary to ensure sustainable land use and stop degradation processes on agricultural lands.

In order to realize the objectives of the program, the regional departments of the State Geocadaster should create schedules for the implementation of meetings, consultations with owners and users of land plots. It is necessary to introduce the practice of broadcasting television programs that would teach and help ordinary citizens to ensure the most rational use of their property, as well as the dissemination of articles with such content in local newspapers.

Another task in a program that requires a permanent solution - consolidation of land. Of course, in order to launch a full process of consolidation of land, a full-fledged agricultural land is needed, but, unfortunately, today no relevant law has been adopted. According to experts, the consolidation of agricultural lands on the basis of the lease is not an ideal solution, since the landlord is mostly not interested in investing in land that is not in his property and trying to get from it only the maximum profit, therefore, so there are disastrous for the environment conditions [3, p.127].

The proposed program for the development of a land management mechanism on agricultural lands does not provide for a solution to the full implementation of consolidation of land, because this issue is rather large. The issues of fragmentation of land are considered internationally. Their decision is being addressed by Ukrainian and foreign scholars. Therefore, this process needs to be continued by providing it through lease and sublease, actively using information from land management schemes and feasibility studies for the respective territories. It is possible to accelerate this process by means of personal messages from owners of agroformings about the expediency of exchange of land plots.

On the basis of the schemes of land management of village and town councils, all types of land management documentation for land tenure and land use should be drawn up. This is especially true of land management projects that provide ecological and economic justification of crop rotation and land management as an instrument of organization and protection. In most administrative regions of Ukraine, agricultural enterprises occupy a significant part of their territory. For this reason, measures planted in the land management scheme are directly related to the organization of the territory of agricultural enterprises and farms. Therefore, the priority task of the program of development of land management mechanism on agricultural lands is the completion of the development 
of land management schemes and feasibility studies for the use and protection of land in all administrative territorial entities. Without this stage, the effectiveness of any design decisions for individual land uses will be questionable and inadequate.

Another of the objectives of the proposed program is to complete the inventory of land. According to the land legislation of Ukraine, inventory of land is carried out with the purpose of setting the location of land, its limits, size, legal status, the identification of unused land, used inappropriately or not for the in- tended purpose, the installation of quantitative and qualitative characteristics of lands necessary for conducting the state land cadastre and so on [4].

The objectives of the second stage of the program are to identify the priority areas requiring the use of land management tools and the choice of program signers. Identification of priority areas must be carried out only on the basis of a corresponding land management scheme. The local department of the State Geocadaster, which is responsible for implementing the program of development of

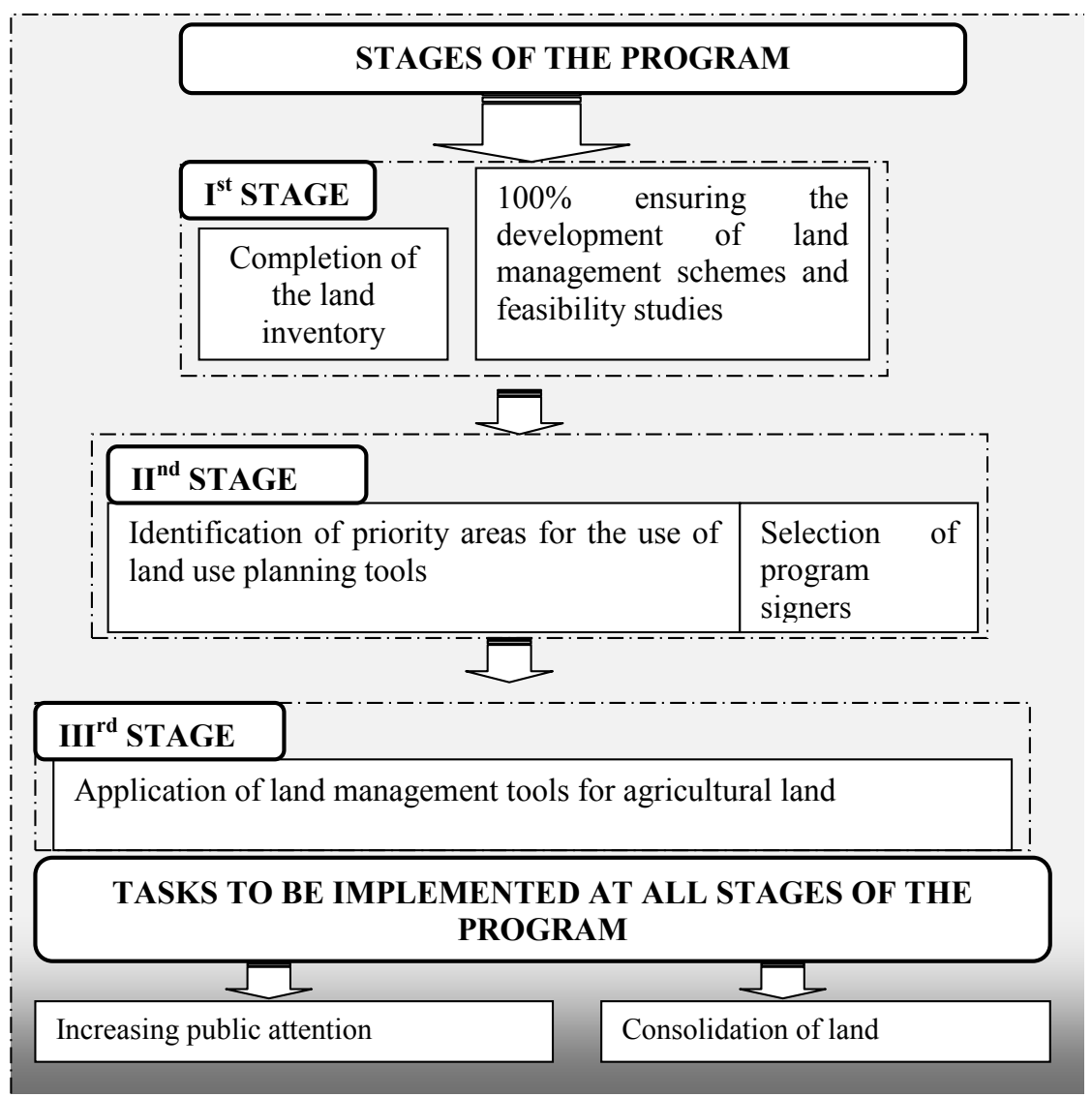

Figure 2. Logical scheme of stages and tasks of the regional program of development of land management mechanism on agricultural lands 


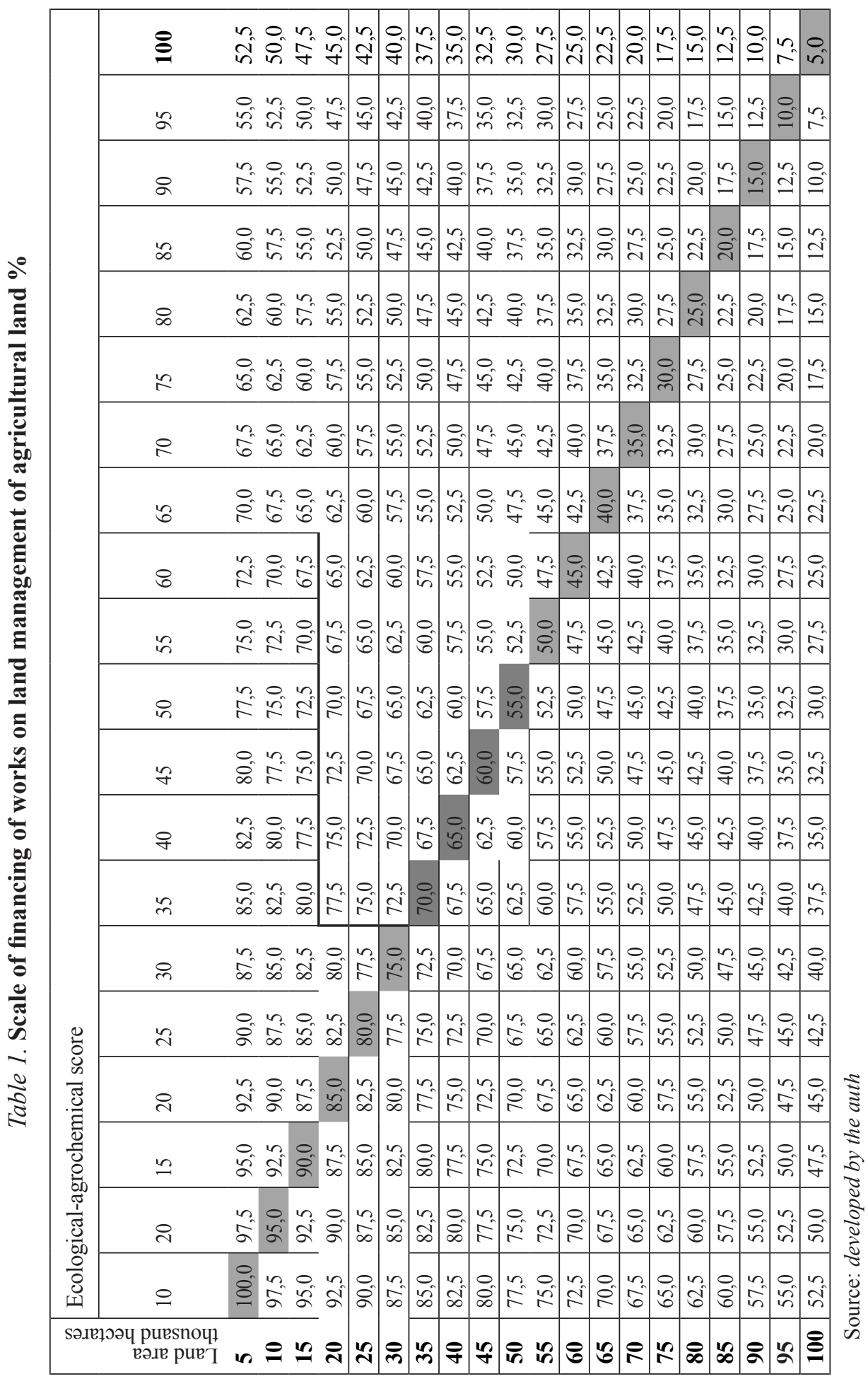


land management mechanism on agricultural lands, is engaged in the definition of such territories.

The financial support of the program should be directed primarily to landowners and land users who must directly apply appropriate organization of land protection. But their financial support should be carried out reasonably, in accordance with the peculiarities of both economic management and existing environmental issues of land resources. To do this, it is necessary to develop a certain algorithm for determining the amount of state support.

The choice of program signatories and the percentage of cash aid aimed at applying land use planning tools to agricultural land should be determined individually for each land use. The percentage of financing for work on the organization and protection of land can be determined by the proposed scale, which characterizes the economy in two indicators: ecological-agrochemical score and land use (table 1). The percentage of state financing necessary measures for the funds provided for the implementation of the program of organization and protection of agricultural land, is set according to the range in which certain land use falls.

Realization of any state programs is possible only with sufficient and stable financial support. It is possible to accomplish the task of the proposed program in a few years, and therefore the planning of financing must be carried out in parallel with the compilation of the regional and local budgets for each calendar year. Subventions for the implementation of the program of organization and protection of agricultural land should be taken from local and regional budgets from funds received from the use of land resources. It is also possible to direct funds for charitable foundations, enterprises, institutions and organizations for the implementation of the land-use machinery development program on agricultural lands, the contributions of individual citizens, funds raised (grants) and other sources not prohibited by law [5].

However, these are not the only sources of funding for the use of instruments of organization and protection of land. Each farm manager can find additional sources of funding for himself, taking into account the peculiarities of his production.

\section{Conclusions.}

As a result of the study, it was determined that timely and scientifically grounded application of land management tools plays a leading role in the way to agricultural use. As a result of the search for the improvement of the stimulation mechanism of sustainable land use, the following components have been identified: territorial development programs and strategies, public attention, social consciousness and reduction of bureaucratic barriers. In connection with this, it is proposed to create regional programs for the development of landuse machinery on agricultural lands in the territory of Ukraine. The program proposes to implement the completion and completion of all necessary land management work with the simultaneous and continuous development of public education and awareness on the rational use of land tenure or land use. The financing of such a program is recommended to be carried out in accordance with the proposed scale of funding for land management of agricultural land. Implementation of land management through territorial development pro- 
grams can become an effective set of actions for agricultural land. The effective functioning of such a program will stimulate landowners and land users to ensure the sustainable use of agricultural land. Real and effective work of such a program is possible with detailed scientific substantiation, economic calculations, determination of responsible persons for its realization and execution. Therefore, the research proposed by us contains significant prospects for the development of which will ensure sustainable land use.

\section{Referenses}

1. Dorosh Y.M. (2012). Napriamy udoskonalennia ekolohichnoi polityky $v$ haluzi zemelnykh vidnosyn [Directions of improvement of ecological policy in the field of land relations]. Zemlevporiadnyi visnyk - Land Management Bulletin, 2, 28-33 [in Ukrainian].

2. Fostolovych V.A., Pryimak L.V. Ekonomichnyi mekhanizm ratsionalnoho vykorystannia ta okhorony zemelnykh resursiv [Economic mechanism of rational use and protection of land resources]. Retrieved from http://econjournal.vsau.org/files/ pdfa/855.pdf [in Ukrainian].

3. Shvorak A.M. (2008). Teoretychni osnovy konsolidatsii zemel: zmist, meta, zavdannia, pryntsypy [Theoretical foundations of consolidation of land: content, purpose, tasks, principles] Zemleustrii i kadastr - Land system and cadastre, 4, 11-13 [in Ukrainian].

4. Ofitsiinyi sait Lvivskoi oblasnoi rady "Pro Stratehiiu rozvytku Lvivskoi oblasti na period do 2020 roku "[Official site of the Lviv Regional Council " On the Strategy for the Development of the Lviv Oblast for the period up to 2020 "] Retrieved from http://www. oblrada.Iviv.ua/news.php?news/500/ group/19Головне управління львівської.

5. Palianychko N.I. Orhanizatsiina skladova v zabezpechenni staloho zemlekorystuvannia [Organizational component in the provision of sustainable land use]. Retrieved fromhttp://economics ofnature.net/uploads/ arhiv/2012/ Palyanychko.pdf [in Ukrainian].

\section{$* * *$ \\ Атаманюк О.П.., Грещук Г.І. ОРГАНІЗАЦІЙНО-ЕКОНОМІЧНИЙ МЕ- ХАНІЗМ СТИМУЛЮВАННЯ СТАЛОГО ВИ- КОРИСТАННЯ ЗЕМЕЛЬ СІЛЬСЬКОГОСПО- ДАРСЬКОГО ПРИЗНАЧЕННЯ}

Удосконалено існуючий механізм стимулювання сталого використання земель сільськогосподарського призначення. Визначено головні складові сучасного стимулювання до сталого використання земель, запропоновано алгоритм, який зможе стимулювати раціональне землекористування з застосуванням землевпорядних інструментів.

Ключові слова: землі сільськогосподарського призначення, стале використання, стимулювання, землевпорядний механізм, програма розвитку, землевпорядкування.

Атаманюк Е.П., Грещук Г.И.

ОРГАНИЗАЦИОННО-ЭКОНОМИЧЕСКИЙ МЕХАНИЗМ СТИМУЛИРОВАНИЯ УСТОЙЧИВОГО ИСПОЛЬЗОВАНИЯ ЗЕМЕЛЬ СЕЛЬСКОХОЗЯЙСТВЕННОГО НАЗНАЧЕНИЯ

Усовершенствован существующий механизм стимулирования устойчивого использования земель сельскохозяйственного назначения. Определены главные составляющие современного стимулирования к устойчивому использованию земель, предложен алгоритм, который сможет стимулировать рациональное землепользование с применением землеустроительных инструментов.

Ключевые слова: земли сельскохозяйственного назначения, устойчивое использование, стимулирование, землеустроительный механизм, программа развития, землеустройства. 